\title{
Translating the sustainable development goals in national development planning: the case of Mozambique's energy for all programme
}

\author{
Eléusio Viegas Filipe ${ }^{1} \cdot$ Kei Otsuki $^{2}$ (1) Jochen Monstadt $^{2}$
}

Received: 23 December 2020 / Accepted: 30 July 2021 / Published online: 21 August 2021

(c) The Author(s) 2021

\begin{abstract}
The international community has emphasised the importance of governments adapting the United Nations Sustainable Development Goals (SDGs) to national policy priorities. Whilst sustainability assessment frameworks and indicators are meant to facilitate adaptation, their assumption of high institutional capacity based on Global North contexts is a shorthand for Global South contexts. In particular, limited institutional capacity means that electricity utilities in the Global South struggle with meeting national and international demands to universalise access to basic services for the entire population as well as in ensuring financial sustainability. Based on a case study of the Mozambique government's National Energy for All Programme, this paper analyses the ways the public electricity company Electricity of Mozambique (known as EDM) has been translating SDG 7.1 on 'ensuring universal access to affordable, reliable and modern energy services' into its national political context given the conditionalities of international donors and investors. One outcome of this translation, a compartmentalisation of EDM's organisational structure, is counterproductive to the integrative and autonomous approach of the SDGs for sustainable development at the national level. To reduce organisational fragmentation and dependency of national project implementers such as EDM on donor interventions, the international community needs to tailor and better align SDG-oriented interventions with the conditions of Southern institutional frameworks and their political contexts.
\end{abstract}

Keywords Electricity $\cdot$ National development planning $\cdot$ SDGs $\cdot$ Sustainability assessment $\cdot$ Mozambique

\section{Introduction}

The Sustainable Development Goals of the United Nations (SDGs) are increasingly incorporated into national-level development policy planning (Chimhowu et al. 2019; Alcamo et al. 2020; Siegel and Bastos-Lima 2020). For example, SDG 7, which aims to 'ensure access to affordable, reliable, sustainable and modern energy for all', largely shapes the energy agendas of countries in the Global South.

Handled by Siddharth Sareen, University of Stavanger, Norway.

Kei Otsuki

K.Otsuki@uu.nl

1 Faculty of Arts and Social Sciences, Department of History, Eduardo Mondlane University, Offices 306/318, Av. Julius Nyerere, PO BOX 257, 3453 Maputo, Mozambique

2 Faculty of Geosciences, Department of Human Geography and Spatial Planning, Utrecht University, Princetonlaan 8A, 3584CB Utrecht, The Netherlands
In particular, as sub-Saharan Africa hosts a significant portion of the world's population without electricity, increasing the 'proportion of population with access to electricity' is a policy priority in nations across the region (Diaz-Sarachaga, et al. 2018). According to Tracking SDG 7: The Energy Progress Report (World Bank 2020), a mere 47 per cent of the population in sub-Saharan Africa was able to access conventional electricity grids in 2018 and the world's 20 least-electrified countries were all located in this region. As electricity is vital component of multiple SDGs, including improved livelihoods, education, communication and technological innovation (Fuso Nerini et al. 2018), governments with low electricity access rates are under both national and international pressure to accelerate electrification rates.

In this context, overseas development assistance and foreign direct investment are recently flowing into the African electricity sector. The increase in international investment is based on the conviction that the major obstacle for electrification in Africa stems from the splintered character of electricity networks and the dire need to fill an 'infrastructural 
gap' (World Bank 2017). However, according to recent scholarly debates, Africa's electrification challenge is rooted not so much in a deficiency remediated through the extension of generation capacity and grids but in the 'fragmented, dispersed, and unregulated set of infrastructures ... outside the formal system of energy governance' (Silver and Marvin 2017, 848). In this context, much attention has been paid to 'understanding how local conditions shape energy services' (Castán Broto 2017, 229) and to various modes of energy co-provisions such as the use of gas, generators, or off-grid solar panels (Jaglin 2014; Baptista 2015; Rateau and Jaglin 2020; Koepke et al. 2021).

Such Southern conditions require policy makers to mobilise 'an array of actors at cross-sectoral levels to develop effective institutions and implement innovative policy frameworks' (Sokona et al. 2012, 3, see also Nilsson et al. 2013). At the same time, national governments are under pressure to become the principal actors in finding ways to translate 'global ambitions to national circumstances and priorities' (Biermann, et al. 2017, 28). Consequently, governments need to implement electrification policies and simultaneously deal with various energy providers and international actors who, through financial support, expect SDG achievement at the national level (Siegel and Bastos-Lima 2020). In addition, in implementing electrification policies, the government is expected to make electricity provision a viable business to ensure financial sustainability and the recovery of costs (World Bank 2020) even though the majority of the population cannot afford to pay market prices for electricity (Republic of Mozambique 2020). The gap between the expectation of financial sustainability and the reality needs to be recognised since this points to the deep inequalities that are at play within a country.

Against this backdrop, we ask the following questions: what coping practices are used by governments in the Global South? National governments are under increasing pressure to realign their national development policies with the SDGs, especially SDG7.1 aimed at ensuring universal access to electricity, yet work under conditions that are markedly different from the Global North. How do governments cope with the conditionality attached to international financial and technological interventions which are promoted under the banner of establishing Global Partnerships (SDG17)? We address these questions by examining the experience of Mozambique, one of the 20 least-electrified countries in the world with a 31 per cent electrification rate in 2018 (World Bank 2020). Mozambique has one of the highest poverty rates in the world as $64 \%$ of the population are living under the international poverty line (World Bank 2021). Its human development index is 0.456 which places the country in the 181 st place out of 189 countries and territories (UNDP 2020). This is despite the fact that, after the end of the socialist regime and prolonged civil war,
Mozambique turned into a 'donor darling' (Shannon 2019; Flento and Simão 2020) and became one of the main foreign direct investment destinations in sub-Saharan Africa, with an annual economic growth rate of 7-8 per cent (Kirshner and Power 2015).

In 2020, the Government of Mozambique published its Voluntary National Review to show its national commitments toward achieving selected SDG targets. As SDG7.1 (ensuring universal access to electricity), was presented as the major public policy goal, the government emphasised the importance of its National Energy for All Programme (Programa Nacional de Energia para Todos). The Programme, launched in 2015 with financial support from the World Bank, aimed to double the electrification rate from 31 per cent in 2018 to 64 per cent by 2024 (Republic of Mozambique 2020, 45; see also World Bank 2020). The Programme was extended in 2019 with the public electricity provider known as Electricity of Mozambique (EDM) put in charge of 'densification and extension of national grids' and National Fund for Energy (FUNAE) responsible for implementing off or mini-grids especially in remote areas (EDM/FUNAE, 2019). In particular, EDM is instrumental in carrying out the electrification policy of the ruling party FRELIMO, ${ }^{1}$ which has established and asserted the power of the national government across its territory through electrification (Power and Kirshner 2019). This government commitment to electrification has led international donors and investors to expand their scope of involvement and influence in electrification projects since the government allowed them to impose conditionality for the implementation of the electrification agenda.

In this paper, we take EDM as an example to explore how a public electricity company tries to implement the SDG agenda in their everyday operations. By doing so, we aim to clarify the likely implications of the current effort to translate and operationalise the SDGs into national development planning. In the next section, we review the literature on the SDGs and sustainability assessment frameworks to show a multiplicity of existing frameworks, which impede a public company like EDM in implementing and evaluating sustainable electrification projects. Section 3 details the methodology of the case study and data collection, while Sect. 4 presents the results of the case study, including the different ways EDM copes with and aligns its electrification projects with national and international demands. In Sect. 5, we summarise an outcome of EDM's coping practices- the

\footnotetext{
${ }^{1}$ FRELIMO stands for Frente de Libertação de Moçambique, Mozambique's Liberation Front founded on 25 June 1962 in Dar Es Salaam, Tanzania by Eduardo Mondlane (1920-1969). Frelimo fought the war of Independence against Portuguese colonialism between 1964 and 1974, and ruled Mozambique ever since (Marcum, 2018, 35-53).
} 
heightened compartmentalisation of EDM's organisational structure-through which social, economic and environmental issues are dealt with separately; we also discuss the implications of this outcome for translating the SDGs into national development planning. Section 6 then provides a conclusion.

\section{The SDGs, sustainability assessment and national development projects}

\section{The assumption for SDG implementation at the national level}

The United Nations General Assembly adopted the SDGs in September 2015 as a way to overcome the shortcomings of the previous Millennium Development Goals (MDGs) (Le Blanc 2015). The MDGs, critically viewed as a top-down and donor-driven process, lacked broad-based consultation and often distorted national and local priorities. At the same time, the MDGs were the world's first global goal-setting governance mechanism, which worked to mobilise 'different constituencies around poverty reduction and [...] reverse the global downturn in development aid levels' (Fox and Stoett 2016, 559-60). Developing countries incorporated the MDGs into national policy frameworks, materialised as Poverty Strategy Papers, which donors used as a tool to organise projects at the national level. The SDGs continued this mobilisation whilst making the process of goal setting more inclusive through broad-based consultation with different governmental and non-governmental actors. The result was a large increase in the number of goals and targets (Waage et al 2015).

According to Biermann et al. (2017, 26), the SDGs 'exemplify a novel type of global governance' with four characteristics. First, this type of global governance is largely detached from the international legal system, and national governments do not have any 'legal obligation to formally transfer the goals into their national legal systems'. Second, the SDG framework functions through 'weak institutional arrangements at the intergovernmental level' in order to foster 'bottom-up, non-confrontational, country-driven, and stakeholder-oriented aspects of governance through goals'. Third, it works through the 'comprehensiveness of the global goal-setting process' and includes advanced economies as stakeholders in the sustainability issues of 'developing countries'. Finally, the SDG framework provides more freedom of choice and options for individual governments (Biermann et al. 2017, 26-7). Together, these characteristics imply that national governments are free to interpret and implement the goals they find most important, but in close collaboration with international partners that are likely to have their own agenda for intervention. In a context in which governments are often perceived as being in constant need of international financial support, as seen in Mozambique, the influence of donors and investors can rise. Moreover, national governments must show that they understand and engage with the SDGs that involve multiple, and sometimes conflicting, objectives (Spangenberg 2017).

For example, SDG7, and especially its target 7.1 which promotes universal access to modern energy, is arguably one of the most needed and yet contentious development goals, as it creates complex trade-offs and synergies in relation to other SDGs (Waage et al. 2015). National governments and donors are keen to make SDG7 a priority since the modern energy sector can simultaneously address many aspects of national development and international interests (Nilsson et al. 2013; Fuso Nerini et al. 2018). The implementation of SDG7 at the national level requires new investments in electricity generation, transmission, distribution and commercialisation, and they must be environmentally sustainable, economically viable and socially inclusive (World Bank 2017). As envisioned in SDG7.2, investments aim to universally switch to electricity from existing off-grid solutions such as charcoal and gas whilst increasing the ratio of renewable energy. As renewable off-grid solutions such as solar home systems remain limited, especially in filling the electrification deficits in sub-Saharan Africa (World Bank 2020), hydroelectric dams are justified despite being controversial as a result of increased methane emissions, natural habitat impairment and physically and economically displacing people (Rogers and Wilmsen 2020).

In such cases, national governments are left to balance, weigh and prioritise conflictive goals and requirements in the absence of an effective 'structure, institution, or mechanism for governing these types of interactions, particularly where they involve conflicts' (Waage et al. 2015, 83). In other words, goal achievement-and the achievement of SDG7 more specifically-inevitably involves political engagement that creates new structures and institutional frameworks or, if necessary, the compartmentalisation of existing mechanisms as we see in our case study below. In this context, sustainability assessment is one method which aims to assist national governments in making political decisions to implement particular SDG targets such as SDG7.1.

\section{The multiplicity of sustainability assessment frameworks and indicators}

The goal of sustainability assessment is to "provide decision-makers with an evaluation of global to local, integrated nature-society systems in short- and long-term perspectives to assist them to determine which actions should or should not be taken in an attempt to make society sustainable' (Ness et al. 2007, 499). More specifically, sustainability assessments and sustainability indicators help 
to: (1) generate information for decision-makers; (2) operationalise sustainable development by attributing meaning to the concept in a given socio-environmental context; (3) initiate learning processes that can lead to a shift in the involved stakeholders and decision-makers' sustainability knowledge, attitudes, and views; and (4) structure complex information (Waas et al. 2014, 5517).

The problem, however, is that studies on the actual use of sustainability assessments and sustainability indicators are largely conducted within specific institutional contexts in the Global North. Moreover, the comprehensiveness of assessing sustainability in the SDGs process remains limited to the project level. For example, an essential indicator for an electrification project is the 'proportion of population with access to electricity' (United Nations 2020, SDG7.1.1, see also World Bank 2020). However, the sustainability of an electrification project requires an assessment across the entire chain of resource extraction, electricity generation, transmission, distribution and sale to capture broader sustainability challenges of actual electrification projects (Nilsson et al. 2013). Any assessment also needs to consider the institutional and political framework as well as the operational and technical capacities of implementing actors including electricity utility companies in the Global South.

Such sustainability assessment limitations stem from the siloed approaches taken by different disciplines (Rotmans 2006). Studies have led to a large number of sustainable development concepts and scenarios related to indicators and models based on narrow geographical, institutional, material and social assumptions. This situation has not changed substantially despite growing scholarly efforts to establish more integrative but 'customised SDG Indices to enhance the appraisal of specific regions' and regional and national development projects (Diaz-Sarachaga et al., 2019, 670).

Nonetheless, practical efforts to localise the SDGs are emerging and indicators are adapted to facilitate SDG implementation by local governments (United Cities and Local Governments 2020). Yet, for national electrification programmes, governments still struggle with applying existing tools in their practical policy making and projects. Consequently, sustainability assessment is associated with a host of other impact assessment tools such as Life Cycle Assessment and Environmental Impact Assessment (Ness et al. 2007; Buytaert et al. 2011). They may also be used in combination with more familiar project evaluation frameworks including Vulnerability Analysis and Cost Benefit Analysis (Taisch et al. 2013). When electrification requires overseas development assistance, as seen in the World Bank funded National Energy for All Programme of Mozambique, the key performance indicators (KPI) of the funding body additionally become important. Project managers on the ground, therefore, have to align multiple sustainability indicators within the same project.

As a result of this situation, project implementation authorities wrestle to 'translate' SDG ideals that inevitably involve 'different social practices, institutional setups, and technical infrastructures' (Monstadt and Schramm 2017, 108). This translation process creates a new reality which has not been adequately addressed in debates about nationalising the SDGs. We examine the translation process of SDG7.1 through our case study on electrification projects implemented under the National Energy for All Programme in Mozambique. Within the particular international demands and national political context, we show that one outcome of this translation is the institutional compartmentalisation of EDM - the electricity utility company at the forefront of implementing SDG-oriented projects. As a result of the multiplicity of required frameworks and indicators, EDM not only struggles with assessing the sustainability of electrification projects, but also with showing SDG achievements.

\section{Methodology: a case study of the National energy for all programme in Mozambique}

\section{Background on Mozambique's electrification programme}

After Mozambique became independent from Portugal on 25 June 1975, the FRELIMO party led the national government and nationalised the majority of private companies. In 1977 and during the third-party congress, FRELIMO declared itself a Marxist-Leninist vanguard political party. Future development was to be achieved through socialism and a centrally planned economy that included state companies such as EDM, cooperatives, and communal villages. Due to the social, economic, and environmental crises that engulfed Mozambique in the 1980s, and marked by the escalation of the civil war, natural disasters, and poor economic performance, the government turned to international financial organisations including the International Monetary Fund (IMF) and the World Bank in 1984. In 1987, the government introduced the Structural Adjustment Programme (Marshall 1990; Hanlon and Smart 2008) which entailed the adoption of a free market economy, the privatisation of state companies, less government intervention in the economy, the reduction of redundant workforce, and fewer subsidies for social services (Flento and Simão 2020). Since then, Mozambique has been dealing with multiple donors and private sector actors for national development planning whilst maintaining the strong, largely authoritarian presence of FRELIMO (Sumich 2010).

EDM - the national and vertically integrated, government-owned electricity company responsible for generating, 
transmitting, and distributing electricity-became a commercial company which nonetheless was overseen by the state in 1995 and strictly followed state-led planning (Decreto 28/95, 17 July); this was followed by a process of system integration, technical and administrative professionalisation, and a continuing search for financial sustainability (Castán Broto et al. 2018: 651). However, by 2007, the country's electrification rate remained at mere 10 per cent (Republic of Mozambique 2020, 45), showing EDM's limited capacity to expand national grids and provide affordable electricity to the majority of Mozambican citizens. Therefore, FUNAE was created in 1997 (Decreto 24/97) to explore off-grid renewable energy solutions, particularly in rural areas.

In 2015, the FRELIMO government officially incorporated the SDGs into its National Five-Year Plan (Plano Quinquenal do Governo) and launched the National Electricity for All Programme (known as Pro-Energia); the programme was financed by the World Bank, housed within the Ministry of Mineral Resources and Energy (hereafter, MIREME), and implemented by EDM and FUNAE. In 2018, the electrification rate was reported to be at 31 per cent (World Bank 2020), and the government turned SDG7 and especially Target 7.1 'ensure universal access to electricity' into a rallying political slogan. To increase the electrification rate to 64 per cent at the end of the current Five-Year Plan and to 100 per cent by 2030, re-elected President Nyusi created an office within the auspices of MIREME to oversee EDM and FUNAE and the implementation of electrification projects in January $2020 .^{2}$

As a commercial company, EDM is supposed to have some degree of administrative autonomy. However, the ruling Frelimo party controls the government and so guides EDM's operation; the party appoints the company's chairman and administrators and provides substantial financial support. As a result, when Eng. Marcelino Gildo Alberto became the new chairman of EDM in June 2020, new institutional frameworks aimed at accelerating the implementation of electrification projects were established. The new frameworks address the government's need to meet conditionalities associated with foreign investments and development assistance as well as align its political objectives with the international development agenda, including the SDGs. One resultant outcomes of this alignment is that EDM is forced to adopt market logic which emphasises cost recovery principles and market access for third parties from the private sector all the while making the cost of electricity

\footnotetext{
${ }^{2}$ A Nossa Agenda é Desenvolver Moçambique (Our Agenda is to Develop Mozambique). Speech of His Excellency Filipe Jacinto Nyusi, on the occasion of the Inauguration Ceremony as President of the Republic of Mozambique, 15 January 2020.
}

affordable to the majority of population such as through the introduction of, for example, 'a policy of social tariffs' (Republic of Mozambique 2020, 45). As we see below, the policy of social tariffs has only had a limited effect, and trying to meet the financial challenges to provide electricity for all has prompted the company to compartmentalise its organisational structure to increase the chance to obtain different donor funds and private investments.

\section{Data collection}

To understand how EDM copes with both national and international political demands in their electrification projects, the lead author visited EDM project sites and conducted 23 interviews with middle and top managers of EDM between March 2018 and December 2019 (a list of interviewees is included as an Annex). At this time, the new Five-Year Plan, aimed at accelerating electrification in Mozambique, was about to be implemented. Interviewees were selected from different directorates that constitute the company while managers were interviewed at the following departments: General Directorate of Distribution; Business Development Directorate; Maputo Regional Directorate; Systems Planning and Engineering Directorate; Renewable Energy and Energy Efficiency Directorate; EDM Academy; and Maputo Sub-Regional Office (which covers the areas of Ka-Guava-Marracuene). The General Director of EDM was also interviewed in the process. At the time of data collection, the General Directorate of Social Energy, which had existed since the MDG period of the 2000s to universalise access to electricity for population who cannot afford market prices, was going through the major reform and resulted in a changed organisational structure in November $2020{ }^{3}$ Therefore, the interview with officials from this specific Directorate could not be conducted. However, information about this reform has been included in the following section.

Outside of EDM, interview data were collected from government officials at MIREME as well as from planners at Maputo City Council, experts at the United Nations Human Settlements Programme (UN-Habitat), from energy and infrastructure experts working for FUNAE, PETROMOC, Solar Works, and donor agencies, namely the World Bank and Japan International Cooperation Agency (JICA).

Each interview featured a small number of interview questions; additional questions were added and reframed in follow-up interviews. This process proved to be useful since it allowed us to sharpen the research objectives, broaden our perspective and cover issues that emerged during the

\footnotetext{
3 The information on the General Directorate of Social Energy was derived from an interview with João Catine, interview, Maputo, 14 October 2019.
} 
research process. We also built a Community of Practice to conduct quarterly focus group discussions where the same officials from EDM, FUNAE, MIREME, and Maputo City Council provided updated information about the progress made and challenges faced in electrification projects. In both the interviews and group discussions, questions centred on: the sustainability assessment frameworks used in electrification projects; the relationships with donors and financial institutions; national requirements for pre-feasibility and feasibility studies; institutional frameworks; funding criteria; and EDM goals, mission, and future strategies.

In the following sections, we present the results of our interviews and discussions to identify how EDM officers and experts from different directorates coped with international demands on financial sustainability whilst meeting various conditionalities as well as national, and ultimately commercially unviable, demands to accelerate universalisation of access to electricity. In the coping process, new technical tools and partnerships emerged. We, thus, introduce these tools and partnerships to discuss the actual implications of translating the SDGs into national development planning processes.

\section{Results: translating SDG7.1 in national electrification projects}

The process of implementing electrification projects at EDM begins within the Directorate of Systems Planning and Engineering. This Directorate is responsible for designing the Integrated Masterplan of Electricity Infrastructures (Plano Integrado de Infraestruturas de Electricidade), which was approved by the Council of Ministers in September $2018 .^{4}$ The Masterplan, financially supported by JICA, is considered to be an important framework that outlines the direction of the national electrification programme, including increased energy production and distribution network expansion for the next 25 years (JICA 2018). Today, EDM's electrification projects are first planned under this Masterplan and then proposed to donors or the national government through MIREME, which also approves the electrification projects of EDM. ${ }^{5}$

Due to the high cost of electricity grid expansion, EDM has relied heavily on foreign support and assistance provided by a wide range of donors and financial institutions, including JICA, the Swedish Development Agency (SIDA), the World Bank, the International Monetary Fund and other bilateral development banks including the German Development Bank (KFW) (for more insight into the role of donors

\footnotetext{
4 António Gimo Júnior, interview, Maputo, 30 October 2018.

5 João Catine, interview, Maputo, 14 October 2019.
}

in the country see: Cramer 2001; Pitcher 2002; Hanlon 2004; Manning and Malbrough 2010; Vollmer 2013; Flento and Simão 2020). In fact, different donors have contributed to the Electrification Fund, which housed within the Ministry of Finance, to ensure the financial resources needed to expand energy provision for the entire country as well as to meet the main indicator for the electrification goal identified by the FRELIMO government in its review of commitments around SDG7: to increase the proportion of the population with access to electricity (Republic of Mozambique 2020, 114).

This means that EDM has to meet the requirements posed by international actors who channel funds through the national government, as widely seen in other national development projects (Vollmer 2013). This interaction between international donors, financial institutions and the national government has been shaping a process by which their different requirements force EDM to implement electrification projects in a particular manner within their capacity.

\section{International demands to be met in practice}

According to João Catine, Project Manager at EDM, donor support for EDM is for the emergency repair and rehabilitation of existing grids and the installation of new grids. When EDM identifies the need of a project, it creates a proposal and contacts donor agencies and financial institutions to assess the proposal to determine its importance and technical and economic feasibility. If the project addresses emergency needs or rehabilitation, it entails strengthening the capacity of power lines and substations. In this case, studies conducted by EDM's Directorate of Systems Planning and Engineering are considered sufficient for donor approval and support. However, if the project entails the building of new grids, donors often impose a conditionality that requires EDM to contract external experts to conduct technical and economic feasibility studies. As one MIREME official puts it:

It is difficult to go around some conditionality [...] there are some that we feel it doesn't make sense to keep our position and lose the investment [...]. Suppose it is a German investment and they want the feasibility study to be conducted by Germans. We recognise our weak technical capacity to undertake such complex studies. [...]. ${ }^{6}$

This already indicates that electrification in Mozambique requires foreign expertise, which does not necessarily enhance the technical capacity of national experts and engineers as is envisioned in SDG Targets 17.8 and 17.9. When a project is deemed feasible, the donor assesses the internal

\footnotetext{
${ }_{6}^{6}$ Pedro Caixote, interview, Maputo, 8 October 2019.
} 
capacity of EDM to implement the proposed project. Institutional capacity in this case indicates the ability to absorb the allocated funding and to manage the project. These assessments end with the design of the Project Implementation Plan, which involves another assessment to determine whether it is necessary to strengthen capacity in areas such as financial management or procurement since donors are also keen to place emphasis on market-driven approaches to project implementation. ${ }^{7}$ No technical capacity development is envisioned in this emphasis on business management.

Upon approval of EDM's administrative board, donors may finance the project following the Implementation Plan. This leads to negotiations on the financial agreements between EDM's administrative board, the Directorate of Projects, and donors. Negotiations are subject to oversight by the Ministry of Economy and Finance and MIREME since any external funding provided to EDM constitutes a public debt, which becomes the government's responsibility. Donors channel their funds to the government and, in turn, the government and EDM sign an agreement for EDM to access the funds for project implementation. ${ }^{8}$

However, as the MIREME official mentioned above, donors from particular countries may demand that consultancy work, materials and equipment acquisition should be done by companies from their home countries (see also Flento and Simão 2020). In a similar vein, an official from the Directorate of Renewable Energy and Energy Efficiency at EDM points out:

For instance, each donor, whether it is Japanese or Norwegian, has its own criteria [for procurement] that we have to follow. So, although EDM has its own criteria [for procurement based on the World Bank policy], it has to comply with the required procedures... When it comes to the procurement process, how to launch the public tender-there is a transparency dimension that they [donors] pay attention to, to see whether there was corruption involved or not [...]. Each donor has its own criteria that are not identical. ${ }^{9}$

Therefore, both feasibility studies and procurement processes required for project implementation involve different consultants from donor countries or consultancy firms approved by the World Bank. In either case, consultants are often paid for some stages of project implementation and sustainability assessment, and this poses challenges to EDM.

\footnotetext{
7 João Catine, interview, Maputo, 14 October 2019.

8 João Catine, interview, Maputo, 14 October 2019.

${ }^{9}$ Olga Utchavo Madeira, also in presence of Círio Muarapaz from the same Directorate and Fabião Cumbe from EDM Academy, CoP meeting / interview, 4 March 2019.
}

A technical engineer, from EDM's General Directorate of Distribution, explains how the utility deals with consultants:

The consultant was present during the first stage of project design [...]. Then, the consultant left during the implementation phase. He was absent but then returned in the end to see the degree of implementation. This is a grave mistake...there is no adequate implementation from the beginning to the end. Consultants are key in the process of implementation. But when consultants are removed, it is complicated and difficult to implement what it is included in the contract documents. ${ }^{10}$

In short, the foreign consultants involved in feasibility studies and project design (colloquially called 'English engineers') tend to leave during actual project implementation only to reappear at the end of the project. This is because donors such as the World Bank do not pay for project inspection. In this situation, EDM has to deal with the provider of a particular system and tools for the project, without having those who recommended the system and tools around for cohesion, capacity-building and support.

By the same token, since EDM relies on external funds to implement projects, the EDM board does not have an overarching strategy for the company. This dependency on donors, not only for financial resources but for expertise needed for completing electrification projects, makes it even harder for the company to provide long-term solutions for the sporadic involvement of consultants in their operations and consistent instructions for the officers to deal with multiple criteria to ensure project sustainability. ${ }^{11}$

\section{National political requirements}

Whilst EDM's project implementation process is largely influenced by the donor-driven feasibility study, financial management, and consultant terms, EDM must simultaneously follow the National Five-Year Plan which is approved by the Frelimo party's Central Committee and congresses ahead of general elections. The public company must follow government priorities to provide electricity to the majority of Mozambique's population who reside in disadvantaged peri-urban and rural communities where the national grid has not yet reached. Such political calculations by the FRELIMO government matter, as the government needs to meet the demands and expectations of a vast electorate located in areas where EDM will not make profits. By doing so, the government can also show that it is pursuing the SDG's general ideal of social inclusion or 'leave no one behind'.

\footnotetext{
10 Sidónio Mabjaia, interview, EDM, 24 October 2019.

11 Néreto Sairosse, interview, EDM, 24 October 2019.
} 
The government, therefore, established the so-called Social Electrification Programme which consists of offgrid electrification by FUNAE as well as EDM's social tariff policies implemented by the General Directorate of Social Energy. The Directorate of Business Development on the other hand focuses on commercially viable projects. However, facing the limited implementation and enforcement of the social tariff policies on the ground, the new chairman of EDM introduced a new organisational structure in November 2020. EDM integrated the Directorate of Social Energy into the Directorate of Electrification and Projects (Direcção de Electrificação e Projectos), which is under the Directorate of System Planning and Engineering within a large division called the Portfolio of Electrification (Portfolio de Electrificação) (EDM 2020). This structural reform was meant to further enable EDM to solicit funds through the Electrification Fund, set up by major donors as the part of the Masterplan, to cover the anticipated losses. According to an EDM engineer:

Looking around to existing models of electricity utilities that strive for sustainable electrification, a special fund for electrification was set up [...] in the Ministry of Finance. In this fund, all mandatory money... [agreed by donors] ... will be deposited and used for social electrification. So, in order to determine how to make use of the money, a committee will be established that will include ... the World Bank, EDM, and other key stakeholders.... If proposed projects are approved, the fund will cover their implementation. ${ }^{12}$

In other words, EDM - as a commercially oriented public company-is increasingly required to classify new projects in terms of both commercial profitability and social inclusivity; this in turn requires the continual reorganisation and compartmentalisation of the company's directorates. As a project manager at EDM, states:

There are situations where grants are justified by the nature of the project, if it is financially feasible or if it is socially [inclusive]. We have the Project for Quality Improvement and Energy Efficiency [PERIP] that benefited from the World Bank grant, but it is an economically-viable project. We have another project that benefited from the World Bank grant for massification of new connections. This is a mixed project in nature; it has a social dimension but it is also economically viable to connect more customers even though these are not commercial customers. We have a Short-Term Investment Project [STIP] that benefited from grants by KFW and the Norwegian Development Agency

$\overline{12}$ Amilton Alissone, interview, Maputo, 15 March 2019.
[NORAD].It is designed to strengthen [the] primary network... [and] ... it is not social. ${ }^{13}$

The nature of the project also justifies which directorate deals with each project. As the sustainability of each project then needs to be assessed, the FRELIMO government proposed the use of the general Environmental Impact Assessment (EIA), updated in 2015, in all new development projects (Decree 54/2015). The EIA outlines the rules guiding pre-feasibility, feasibility and evaluation studies that national and foreign consultants must follow in every development project. It also establishes a classification of projects, namely $\mathrm{A}, \mathrm{B}$, and $\mathrm{C}$ categories: A category projects, such as largescale dam construction, require full-fledged assessment as they generate significant impacts; B category projects, such as electricity distribution networks which require a simplified EIA, have less impacts on the environment; and C category projects have minimum impacts and therefore no EIA is required (Netherlands Commission for Environmental Assessment 2020). As most new electrification projects fall under the B category, all consultants are required to submit their EIAs for government approval. ${ }^{14}$ Our informants from the Directorate of Renewable Energy and Energy Efficiency and EDM Academy point out that:

We design the project followed by the feasibility study. [...]. When it comes to project standards, particularly in terms of technical and environmental specifications, we have to comply with Mozambican legislation. We have to comply with the rules of the Ministry of Land, Environment and Rural Development (MITADER) [when the project involves a large-scale land acquisition], EDM standards, and electricity legislation. ${ }^{15}$

This quote shows that EDM's operations are heavily influenced by governmental regulations. In addition, the government often requires a cost-benefit analysis. Consequently, EDM aims to both generate profits and reduce the costs associated with production and distribution by selling electricity to commercial customers whilst trying to achieve access targets as well as environmental objectives. In order to facilitate this balancing act by EDM, donors and private sector actors who cooperate with the government have introduced EDM to a variety of project management tools.

\footnotetext{
13 João Catine, interview, Maputo, 11 December 2019.

14 Amilton Alissone, interview, Maputo, 15 March 2019.

15 Olga Utchavo Madeira, Fabião Cumbe, Círio Muarapaz, CoP meeting / interview, 4 March 2019.
} 


\section{Project management tools}

The tools required for project management are called 'special tools' (ferramentas especiais) and include software introduced in the context of Southern African Power Pool (SAPP) as well as the Wien Automatic System Planning Package (WASP), which was acquired based on Mozambique's status as a member state of the International Atomic Energy Agency. These tools help to simulate the sustainable use of resources in electricity generation and to estimate the costs of maintenance, operation and output for distribution. They are also used to determine the feasibility of the construction and implementation of hydropower plants and gas-powered stations. ${ }^{16}$

Once an electrification project is underway, EDM uses Network and Customer Information System (NCIS) software, which EDM purchased from a Swedish company. ${ }^{17}$ The NCIS allows the utility to build and maintain a database of existing grids with information about low- and mediumvoltage lampposts and customers. It also allows users to generate power flow simulations and calculations to better understand existing availability for advanced analysis as well as to anticipate risks, disruption or malfunctioning grids. This process is followed by area inspections and data collection using GPS. Using the NCIS, EDM assesses: 1) the potential impact of electrification on existing infrastructure such as schools and hospitals; and 2) whether additional investments should be made through commercial or social projects. For social projects, the utility pays particular attention to household consumption, customer profile, potential growth and house and street types in order to assess the commercial sustainability of a project. The NCIS is said to be, 'from a technical viewpoint, the best tool', ${ }^{18}$ as it enables different types of analysis and the ability to explore possible scenarios.

However, because the software is not available to all EDM directorates, fragmentation among different directorates and departments ensues. The software is also incompatible with other system software, as it is solely used by departments to deal with different suppliers (often foreign) based on each approved electrification project. When any EDM directorate does not have the expertise to utilise existing tools or to construct new systems, some operations are outsourced altogether.

\section{Public-private partnerships}

Apart from international donors, EDM has increasingly partnered with private investors by creating a framework called Project for Finance where projects are expected to generate enough returns to pay off the fees and taxes accrued by these investors. For interested private companies, EDM creates commercially profitable projects designed to generate electricity and further attract the interest of other private companies and sponsors. For example, private investors were involved in building super high voltage power networks to supply electricity to the southern part of the country (referred to as the backbone) or to the neighbouring country of Malawi.

When EDM partners with private companies in the construction of power stations or high voltage distribution networks, it has to fulfil its share of financial obligations. To do so, EDM may solicit financial support in the international market, which is distinct from international donor support. According to an EDM official:

In these kinds of situations, the utility doesn't approach institutions or organisations that support us for social projects or development projects [...] [instead the company approaches] [...] institutions that have expertise in providing financial assistance for commercial investments-these institutions not only support the government but they often support EDM [directly]. ${ }^{19}$

However, when electricity projects are strategic in a sense that they can be linked to the national electrification plan, some donors (namely those that traditionally support the country using 'corporate finance'), also provide financial support to EDM to cover EDM's portion of an investment.

In addition, EDM often outsources some of its operational units that are deemed to be outside EDM's areas of expertise. For instance, EDM has outsourced customer service and the handling of all inquiries and requests from customers to Mozambique Telecom Company (Mcel) ${ }^{20}$ This way, EDM pragmatically copes with its inability to meet the challenges of an expanded customer base as the electrification project accelerates. Likewise, private sector participation is promoted at FUNAE in collaboration with EDM, which supplies disconnected customers in rural regions by building or operating mini-grids and renewable energy plants.

\footnotetext{
19 João Catine, interview, Maputo, 11 December 2019.

${ }^{20}$ A recent merger between the two public companies Mozambique Telecommunications (TDM) and Mozambique Cellphone Company (Mcel) led to the creation of Tmcel.
}

16 António Gimo Júnior, interview, Maputo, 30 October 2018.

17 Information given in this paragraph is based on the interview with Amilton Alissone, Maputo, 15 March 2019.

18 Amilton Alissone, interview, Maputo, 19 March 2019. 


\section{Discussion: the outcome of EDM's translation of SDG7.1}

The results presented above, obtained from the interviews and discussions with EDM officials and other experts, indicate that electrification projects are shaped and assessed based on a range of international and national requirements related to meeting SDG7.1. Consequently, the introduction and use of different tools and software packages within different parts of EDM exacerbate institutional and project fragmentation. Moreover, instead of strengthening the expertise needed by EDM to take an integrative approach to sustainable electrification, commercial viability of the fragmented projects is ensured as different operations are outsourced through partnerships with private investors and other companies.

Ideally, SDGs promote an integrative approach toward implementing social, economic, and environmental sustainability targets (Le Blanc 2015). However, in order to address these three dimensions of sustainability, EDM has translated them by compartmentalising mechanisms of its institutional setup. For example, the commercial viability of new grid extension and connection is dealt with in the Directorate of Business Development whilst environmentally sustainable forms of power generation are being planned at the Directorate of Renewable Energy. When the renewable off-grid solutions are sought, the operation is relegated to FUNAE. And, most importantly, the political goal of achieving universal access by 2030 was reintegrated into the entire structure of the division of the Portfolio of Electrification; this division in turn integrates the former Directorate of Social Energy and the Directorate of Electrification and Projects where financial loss is covered by the newly established Electrification Fund. Further, the environmental assessment of the grid development is completed by external contractors.

In fact, since the MDG time, EDM and its former Directorate of Social Energy had been expected to contribute to factors that dictate poverty alleviation through universal electrification. However, social electrification through the Directorate did not elevate the electrification rate which remained at 31 per cent in 2018 (World Bank 2020). This could result in part from the lack of alignment between the goal of social inclusivity and EDM's existing operational capacity. Current SDG requirements have become a stronger force to the compartmentalisation, presumably because of the government's strong will to attract and use donor funds and foreign investments to pursue the universal access to electricity agenda, not only to achieve SDG7 but also in relation to other goals including SDG1: no poverty (Fuso Nerini et al. 2018).
In short, in an effort to translate SDG7, especially Target 7.1 of ensuring universal access to electricity and to achieve other SDGs simultaneously, EDM has been reorganising and compartmentalising its institutional setup to a greater extent than during the pre-SDG period. And in each compartment, external contractors perform both feasibility studies and EIAs. This procedure hardly develops the capacity of EDM experts nor does it integrate all three dimensions of EDM's strategic planning or its daily operations. As a result, the promotion of low-carbon alternatives such as renewables or obtaining higher energy efficiency for existing electrification projects remains limited (World Bank 2020). In this context, the government has assigned the responsibility of promoting renewable energies and off-grid solutions-as the key strategy to implement SDG7 in peri-urban or rural areas, which are not connected to EDM's electricity grid-to FUNAE. FUNAE receives its own financial support, and its projects remain rather ad hoc; this reflects the increasing 'projectisation' of public services which tends to make visible the inequality of service access (Picciotto 2020).

It remains to be seen whether such dependency on external donors, investors and contractors and the compartmentalisation of EDM's operations will help raise the electrification of Mozambique from 31 per cent (2018) to 64 per cent in 2024 and ultimately to 100 per cent in 2030 as envisioned in the National Five-Year Plan. In particular, we need to pay close attention to how the universalisation policy that underpins the National Energy for All Programme leads to institutional compartmentalisation and project fragmentation and whether the poor truly benefit from these processes in the long run.

\section{Conclusions}

Our main objective in this paper is to generate an understanding of how SDGs are translated in national development projects. By looking into the daily operations of EDM, which strives to carry out the National Energy for All Programme and universalise electricity access, we have shown that the Mozambique's effort to achieve SDG7 through electrification projects is highly politicised. In this context, project implementers such as EDM are forced to introduce new organisational structures in order to meet the various conditions, requirements, and tools imposed by national and international actors.

More specifically, our case study has shown that international development assistance-provided to the national government to align its policies with the SDGs-comes with strings attached; this has compelled the public electricity company to adapt its structure and operations, create separate directorates, and relegate project implementation for off-grid renewable solutions to FUNAE. In each 
compartmentalised organisational structure and institutional framework, project managers strive to meet sustainability criteria. However, their capacity to do so remains limited, and they are dependent on external experts or forced to seek out new partnerships with other public and private actors. In this sense, the SDGs are not neatly implemented within the existing institutional setup but instead are translated by way of institutional compartmentalisation.

This aspect requires more scholarly attention since it implies that the SDGs drive further institutional reform in countries where Structural Adjustment Programmes had integrated national governments into the global economic order in rather incremental and implicit ways. By forcing governments to accelerate their commitment to achieving sustainability, donors and international financial institutions keep promoting structural adjustments in the Global South to better fit their investment schemes. This is also done through the SDG objective of building global partnerships that aim at more efficient operations in public companies. In this process, little capacity development has been devoted to training national experts, engineers and planners in conducting independent feasibility studies and project assessments. Moreover, most technical tools used to further consolidate the sustainability of these projects are provided by foreign companies, and little domestic technology development is envisioned. We have seen that whilst one outcome of the SDG7 implementation process is increased partnership, this could lead Southern countries toward increased dependency on the sustainability expertise and tools of the Global North.

Increased compartmentalisation and donor dependency, through the translation of SDGs, are a convenient way for Mozambique's largely authoritarian FRELIMO government to nominally show (or "make believe") their engagement with and achievements around the international agenda (Flento and Simão 2020). The international community needs to be aware that this situation contradicts the 2030 Agenda which promotes an integrative approach to sustainable development and an autonomous and bottom-up process of adapting the SDGs to national development policy priorities. The World Bank, as the leading financial institution in infrastructure projects in the Global South, and more generally donors that finance separate projects, could more consciously align and streamline their funding mechanisms to link business development with the universalisation of basic services access. Instead of obliging a public company to report on one aspect (e.g. the proportion of population having access to clean electricity) separately from others (e.g. the profitability of an electrification project or its environmental impact), donors could train the company's managers and government officials on how to build a strategy that redistributes the benefits derived from commercially viable projects and serves people and areas where profitability is low. Instead of sporadically sending foreign consultants to different projects and in different phases, donors could sponsor consultants to work together with national officials and engineers. In this way, better linkages and alignments to national conditions and requirements could be established between different projects and international frameworks and tools.

In other words, the international community should anticipate that SDG implementation on the ground creates consequences that require a long-term strategy to help the national implementer deal with the compartmentalisation of its operations as well as the implications stemming from a lack of access to basic services and the reduction of inequality. As we enter the last decade of the 2030 Agenda, the current imperative is to amplify investigation into the ways various SDG-oriented projects are translated in national and local development projects in different countries. By doing so, we can more fruitfully envision a post-2030 Agenda and the sustainability of SDG projects.

Supplementary Information The online version contains supplementary material available at https://doi.org/10.1007/s11625-021-01020-y.

Acknowledgements The research was conducted at the Faculty of Geosciences at Utrecht University as a part of the project 'Coping with Urban and Infrastructural Heterogeneity: Sustainable Energy Transitions in Tanzania and Mozambique' (URBAN-HIT), funded by the Dutch Research Council (NWO) under grant number W07.303.107. We would like to thank all of the participants taking part in the interview sessions and Community of Practice meetings held in Maputo and Dar es Salaam between 2018 and 2020.

Open Access This article is licensed under a Creative Commons Attribution 4.0 International License, which permits use, sharing, adaptation, distribution and reproduction in any medium or format, as long as you give appropriate credit to the original author(s) and the source, provide a link to the Creative Commons licence, and indicate if changes were made. The images or other third party material in this article are included in the article's Creative Commons licence, unless indicated otherwise in a credit line to the material. If material is not included in the article's Creative Commons licence and your intended use is not permitted by statutory regulation or exceeds the permitted use, you will need to obtain permission directly from the copyright holder. To view a copy of this licence, visit http://creativecommons.org/licenses/by/4.0/.

\section{References}

Alcamo J, Thompson J, Alexander A et al (2020) Analysing interactions among the sustainable development goals: findings and emerging issues from local and global studies. Sustain Sci 15:1561-1572. https://doi.org/10.1007/s11625-020-00875-x

Baptista I (2015) "We live on estimates": everyday practices of prepaid electricity and the urban condition in Maputo, Mozambique. Int J Urban Reg Res 39:1004-1019. https://doi.org/10.1111/14682427.12314

Biermann F, Kanie N, Kim RE (2017) Global governance by goalsetting: the novel approach of the UN sustainable development goals. Curr Opin Environ Sustain 26-27:26-31. https://doi.org/ 10.1016/j.cosust.2017.01.010 
Le Blanc D (2015) Towards integration at last? The Sustainable development goals as a network of targets. The United Nations Department of Economic and Social Affairs Working Paper 141. wp141_2015.pdf (un.org). Accessed 22 Dec 2020

Buytaert V, Muys B, Devriendt N, Pelkmans L, Kretzschmar JG, Samson R (2011) Towards integrated sustainability assessment for energetic use of biomass: a state of the art evaluation of assessment tools. Renew Sustain Energy Rev 15:3918-3933. https://doi. org/10.1016/j.rser.2011.07.036

Castán Broto V (2017) Energy sovereignty and development planning: the case of Maputo, Mozambique. Int Dev Plan Rev 39:229-248. https://doi.org/10.3828/idpr.2017.9

Castán Broto V, Baptista I, Kirshner J, Smith S, Alves SN (2018) Energy justice and sustainability transitions in Mozambique. Appl Energy 228:645-655. https://doi.org/10.1016/j.apenergy. 2018.06.057

Chimhowu AO, Hulme D, Munro LT (2019) The 'New' national development planning and global development goals: processes and partnerships. World Dev 120:76-89. https://doi.org/10.1016/j. worlddev.2019.03.013

Cramer C (2001) Privatisation and adjustment in Mozambique: a 'hospital pass'? J South Afr Stud 27:79-103. https://doi.org/10.1080/ 03057070120029518

Diaz-Sarachaga JM, Jato-Espino D, Castro-Frenso D (2018) Is the sustainable development goals (SDG) index an adequate framework to measure the progress of the 2030 Agenda? Sustain Dev 26:663-671. https://doi.org/10.1002/sd.1735

Electricidade de Moçambique (EDM) (2020) Estrutura Orgânica Completa. https://www.edm.co.mz/pt/website/page/estrutura-org\% C3\%A2nica. Accessed 17 Aug 2021

Flento J, Simão LS (2020) Donor relations and sovereignty. UNU-WIDER

Fox O, Stoett P (2016) Citizen participation in the UN sustainable development goals consultation process: toward global democratic governance? Glob Gov 22:555-573. https://doi.org/10. 1163/19426720-02204007

Fuso Nerini F, Tomei J, Seng To L, Bisaga I, Parikh P, Black M, Barrion A, Spataru C, Castán Broto V, Anandarajah G, Miligan B, Mulugetta $Y$ (2018) Mapping synergies and trade-offs between energy and the sustainable development goals. Nat Energy 3:10-15

Hanlon J (2004) Do donors promote corruption? The case of Mozambique. Third World Q 25:747-763. https://doi.org/10.1080/01436 590410001678960

Hanlon J, Smart T (2008) Do bicycles equal development in Mozambique? James Currey, Woodbridge

Jaglin S (2014) Regulating service delivery in southern cities: rethinking urban heterogeneity. In: Parnell S, Oldfield S (eds) The Routledge handbook on cities of the Global South. Routledge, London and New York, pp 434-447

Japan International Cooperation Agency (JICA) (2018) Integrated Master Plan: Mozambique power system development. Final Report, JICA. https://openjicareport.jica.go.jp/pdf/12318606.pdf

Kirshner J, Power M (2015) Mining and extractive urbanism: postdevelopment in a Mozambican boomtown. Geoforum 61:67-78

Koepke M, Monstadt J, Pilo F, Otsuki K (2021) Rethinking energy transitions in southern cities: urban and infrastructural heterogeneity in Dar es Salaam. Energy Res Soc Sci 74(2021):101937. https://doi.org/10.1016/j.erss.2021.101937

Manning C, Malbrough M (2010) Bilateral donors and aid conditionality in post-conflict peacebuilding: the case of Mozambique. J Mod Afr Stud 48:143-169. https://doi.org/10.1017/S0022278X0 9990255

Marcum JA (2018) Conceiving Mozambique. Palgrave Macmillan
Marshall J (1990) Structural adjustment and social policy in Mozambique. Rev Afr Polit Econ 47:28-43. https://doi.org/10.1080/ 03056249008703846

Monstadt J, Schramm S (2017) Toward the network city? Translating technological ideals and planning models in water and sanitation systems in Dar es Salaam. Int J Urban Reg Res 41:104-125. https://doi.org/10.1111/1468-2427.12436

Ness B, Urbel-Piirsalu E, Anderberg S, Olsson L (2007) Categorising tools for sustainable assessment. Ecol Econ 60:498-508. https:// doi.org/10.1016/j.ecolecon.2006.07.023

Netherlands Commission for Environmental Assessment (2020) Mozambique: EIA profile. https://www.eia.nl/en/countries/mozam bique. Accessed 6 May 2021

Nilsson M, Lucas P, Yoshida T (2013) Towards an integrated framework for SDGs: ultimate and enabling goals for the case of energy. Sustainability 5:4124-4151. https://doi.org/10.3390/su5104124

Picciotto R (2020) Towards a 'New Project Management' movement? An international development perspective. Int J Project Manage 38(8):474-485

Pitcher A (2002) Transforming Mozambique: the politics of privatization 1975-2000. Cambridge University Press, Cambridge

Power M, Kirshner J (2019) Powering the state: the political geographies of electrification in Mozambique. Environ Plan C Polit Space 37:498-518. https://doi.org/10.1177/2399654418784598

Rateau M, Jaglin S (2020) Co-production of access and hybridisation of configurations: a socio-technical approach to urban electricity in Cotonou and Ibadan. Intern J Urban Sustain Dev Press. https:// doi.org/10.1080/19463138.2020.1780241

Republic of Mozambique (2020) Report voluntary national review of agenda 2030 for sustainable development. Maputo. https://susta inabledevelopment.un.org/content/documents/26314VNR_2020_ Mozambique_Report.pdf

Rogers S, Wilmsen B (2020) Towards a critical geography of resettlement. Prog Hum Geogr 44(2):256-275

Rotmans J (2006) Tools for integrated sustainability assessment: a twotrack approach. Integr Assess J 6:35-57

Shannon M (2019) African urban development in a post-aid era: the 'Dutch Approach' to urban restructuring in Beira City, Mozambique. Built Environ 44:397-419

Siegel K, Bastos-Lima MG (2020) When international sustainability frameworks encounter domestic politics: the sustainable development goals and agri-food governance in South America. World Dev Press. https://doi.org/10.1016/j.worlddev.2020.105053

Silver J, Marvin S (2017) Powering sub-Saharan Africa's urban revolution: an energy transitions approach. Urban Studies 54:847-861. https://doi.org/10.1177/0042098016668105

Sokona Y, Mulugetta Y, Gujba H (2012) Widening energy access in Africa: towards energy transition. Energy Policy 47 47:3-10. https://doi.org/10.1016/j.enpol.2012.03.040

Spangenberg JH (2017) Hot air or comprehensive progress? A critical assessment of the SDGs. Sustain Dev 25:311-321. https://doi. org/10.1002/sd.1657

Sumich J (2010) The party and the state: Frelimo and social stratification in post-socialist Mozambique. Dev Chang 41:679-698. https://doi.org/10.1111/j.1467-7660.2010.01653.x

Taisch M, Sadr V, May G, Stahl B (2013) Sustainability assessment tools-state of research and gap analysis. In: Vittal P, Taisch M, Kiritsis D (eds) Advances in production management systems. Springer, London, pp 227-234

The World Bank (2017) Africa's pulse, 15. http://documents.world bank.org/curated/en/348741492463112162/Africas-pulse. Accessed 22 Dec 2020

The World Bank (2020) Tracking SDG 7: the energy progress report 2020. The World Bank, Washington DC

The World Bank (2021) Mozambique economic update. https://openk nowledge.worldbank.org/bitstream/handle/10986/35214/Mozam 
bique-Economic-Update-Setting-the-Stage-for-Recovery.pdf? sequence $=1 \&$ isAllowed $=y$. Accessed 8 July 2021

United Cities and Local Governments (2020) Localizing the SDGs. https://www.learning.uclg.org/. Accessed 5 May 2021

United Nations Development Programme (UNDP) (2020) Human development report 2020: the next frontier-human development and the Anthropocene. United Nations, New York

United Nations (2020) Sustainable Development Goals: ensure access to affordable, reliable, sustainable and modern energy. https:// www.un.org/sustainabledevelopment/energy/. Accessed 10 April 2020

Vollmer F (2013) The changing face of Africa: Mozambique's economic transformation and its implications for aid harmonisation. Ir Stud Int Aff 24(2013):137-164

Waage J, Yap C, Bell S, Levy C, Mace G, Pegram T, Unterhalter E et al (2015) Governing sustainable development goals: interactions, infrastructures, and institutions. In: Waage J, Yap C (eds) Thinking beyond sectors for sustainable development. Ubiquity Press, London, pp 79-88

Waas T, Hugé J, Block T, Wright T, Benitez- Capistros F, Verbruggen A (2014) Sustainability assessment and indicators: tools in a decision making strategy for sustainable development. Sustainability 6:5512-5534. https://doi.org/10.3390/su6095512

Publisher's Note Springer Nature remains neutral with regard to jurisdictional claims in published maps and institutional affiliations. 